\title{
CASE STUDY AS A LEARNING OPPORTUNITY AMONG NURSING STUDENTS IN A UNIVERSITY
}

Author:

Jackie M.L. Malesela ${ }^{1}$

\section{Affiliation:}

${ }^{1}$ Department of Nursing

Science, University of

Johannesburg, South

Africa

\section{Correspondence to:}

Jackie M.L. Malesela

e-mail:

jackiem@uj.ac.za

\section{Postal address:}

Department of Nursing Science, University of Johannesburg, PO Box 524, Auckland Park 2006, Johannesburg, South Africa

\section{Keywords:}

case study; learning opportunity; nursing students; South African university teaching; nursing science

\section{Dates:}

Received: 21 July 2008

Accepted: 04 Dec. 2008

Published: 25 June 2009

How to cite this article: Malesela, J.M.L., 2009, 'Case study as a learning opportunity among nursing students in a university', Health $S A$ Gesondheid 14(1),

Art. \#434, 6 pages. DOI: 10.4102/hsag.v14i1.434

\section{This article is available} at:

http://www.hsag.co.za (c) 2009. The Authors. Licensee: OpenJournals Publishing. This work is licensed under the Creative Commons Attribution License.

\section{ABSTRACT}

The South African Qualification Authority Act (58/1995) requires that the facilitators of the education and training programme for nursing students implement teaching strategies that facilitate critical reflective thinking and lifelong learning. This article seeks to report fourth-year nursing students' experiences regarding the use of a case study approach as a learning opportunity. Much has been documented about the case study as an effective strategy to facilitate learning.

A purposive convenience sampling method was used to select 24 nursing students in a South African university. Descriptive naïve sketches were used to collect data. The results were analysed using the content data analysis method (Burns \& Grove 2003). Measures to ensure the trustworthiness of the study were taken in accordance with Lincoln and Guba's (1985) principles. Ethical standards for research were observed in order to maintain the integrity of the research.

The research findings suggest that the case study as a learning opportunity is effective in facilitating learning, as indicated by the following three categories: increase in critical thinking skills, increased theory and practice integration and increased growth in presentation skills. These categories were conceptualised using the relevant literature in order to describe research-based recommendations regarding the use of a case study approach as a learning opportunity. It is recommended that facilitators involved in the nursing education programme make use of a case study approach as a learning opportunity at all levels of the nursing education programme.

\section{OPSOMMING}

Die Suid Afrikaanse Qualification Authority Act (58/1995) vereis dat die fasiliteerders van die onderrig en opleiding program vir verpleegkunde studente onderrig strategië implimenteer wat kritiese reflektiewe denke en lewenslange leer fasiliteer. Die dokument poog om 4 de jaar verpleegkunde studente se leerervaring in verband met gevalle-studie benadering te rapporteer. Baie is al gedokumenteer oor die kern van die gevalle-studie as 'n effektiewe strategie om leer te fasiliteer.

Die doelgerigte gerieflikheids steekproef metode was gebruik om 24 verpleegkunde studente in 'n Suid Afrikaanse universiteit te kies. Deskriptiewe, naïve sketse was gebruik om inligting te versamel. Resultate was ge-analiseer deur middel van die inhoud data analiese metode (Burns \& Grove 2003). Mates om die vertrouens-waardigheid van die studie te verseker was gevolg volgens Lincoln en Guba (1985) se beginsels. Etiese standaarde vir navorsing was waargeneem om die integriteit van die navorsing te verseker.

Navorsings bevindinge dui daarop dat die gevalle-studie as leer geleentheid effektief was in die fasilitering van leer, soos aangedui deur die volgende drie kategorië: vermeerdering van kritiese denke vaardighede; vermeerderde teorie en praktyk integrasie en vermeerderde groei in aanbiedings vaardighede. Hierdie kategorië was gekonseptualiseer deur die gebruik van toepaslike literatuur sodat navorsings-gebaseerde aanbevelinge in verband met gevalle-studie benadering as leer geleentheid beskryf kon word. Dit word aanbeveel dat fasiliteerders betrokke by die verpleeg onderrig program gebruik maak van gevalle-studie benadering op alle vlakke van die verpleeg program.

\section{INTRODUCTION}

Nurse educators in South Africa are faced with the challenge of developing teaching strategies that promote nursing students' reflective and critical thinking and help them to become lifelong learners. Critical thinking will enable nursing students to meet the patient's needs arising from dynamic changes within the health care system, such as the disease profile within a multicultural society.

The growing interest in the use of the case study and case presentation as a teaching and learning facilitation strategy suggests that knowledge, skills, attitudes and values in clinical nursing education are inseparable and integral components. This strategy has taken the form of complex real and/or hypothetical narratives grounded in actual problems and challenges that occur in real nursing care environments where integration of theory and practice should occur.

According to Knowles's andragogic theory (cited in Mellish, Brink \& Paton 1998:36) nursing students as adult learners want to be self-directed and self-monitoring and want to see the usefulness of the content they are learning. Past experiences are used as a frame of reference to understand learning activities meaningfully. Adult learners enjoy active participation in learning activities and take responsibility for their own learning. The case study method of teaching provides a means for applying problem-solving skills and making decisions in a non-threatening environment. Case studies allow student nurses to 'experience' actual patient situations and encourage student nurses to have a sense of ownership and belonging. The use of the case study, through its interactive and exploratory nature, 
demonstrates that there may be multiple 'correct' solutions for individual clinical problems (Draude 1996:103; Sandstrom 2006:229; Schryer et al. 2003:65).

Studies have been conducted regarding the value of the case study as a strategy to facilitate teaching and learning in undergraduate nursing education programmes. Conyers and Ritchie (2001), Draude (1996), Hannah (2006) Schryer et al. (2003) and Sandstrom (2006) share the view that case studies provide opportunities for student nurses to examine given situations from multiple perspectives, which leads to an increase in their understanding of given case phenomena and transfer of knowledge from theory to practice. However, little is known regarding how nursing students experienced the use of the case study as a learning opportunity.

\section{PROBLEM STATEMENT}

The South African Qualification Authority (SAQA) Act no. 58 of 1995 demands that the training and education programme for nursing students produce, amongst other things, a cadre of nurses who are critical, reflective thinkers and lifelong learners. This demand has led to a paradigm shift in nursing education from the traditional teacher-based to a more leaner-based approach. A case study, like other dialogic teaching strategies such as role play, poster presentation and debate, meets this demand in clinical nursing because of the need to integrate theory into practice. Sandstrom (2006:229) indicated that the case study method of teaching enables students to develop a clearer understanding of the disease, how it affects patients and their needs and how patients respond to their illness.

The literature regarding the use of the case study as a learning facilitation strategy focuses primarily on the outcome of the learning process and on the ability of this strategy to equip nursing students with the desired learning skills. Previous studies on the case study as a method of teaching did not focus on how the student nurses themselves experienced the case study as a learning opportunity. Knowing and understanding the dynamic experiences of the students regarding the case study as a learning opportunity could culminate in an importan didactic improvement in the use of the case study in clinical nursing education. From the introduction and the problem statement, the following research question emerged: What are the experiences of fourth-year BCur students regarding the use of a case study as a learning opportunity?

\section{AIM OF THE RESEARCH}

The aim of this study was to explore and describe fourth-year BCur students' experience regarding the use of the case study as a learning opportunity in clinical nursing education. The research-based recommendations to improve the use of case studies as a learning opportunity will be described from the students' experiences.

\section{DEFINITION OF CONCEPTS}

\section{Case study}

The case study is '...like snap shots of a scenario during a specific period in time where you are asked to evaluate that snapshot and answer certain questions' (Winningham \& Preusser 2001:4). In other words, a case study is a tool for engaging nursing students in reflective discussion, thus encouraging higher order thinking and creative problem-solving abilities in the learners. In nursing education, a case study can be a snapshot of a scenario that took place and /or is taking place in any nursing/health care environment and can also be a deliberate creation of a scenario by the nurse educator in a simulated environment in order to correlate theory with practice.

\section{Learning opportunity}

The Compact Oxford English Dictionary (Soanes, \& Hawker 2005:562) defines learning as 'knowledge or skill gained through study or by being taught' and an 'opportunity as a favorable time or a set of circumstances for doing something'. Therefore, for the purpose of this study, a learning opportunity is the systematic acquisition of knowledge using the right set of circumstances. These circumstances can be a real health care learning environment or a purposefully selected classroom setting.

\section{Nursing students}

In this study, a student nurse is a learner registered for a fouryear nursing degree course leading to registration as a nurse (general, psychiatric and community) and midwife, according to South African Nursing Council Regulation R425 of 22 February, 1985 , as amended.

\section{Research design}

\section{RESEARCH METHOD}

A qualitative, exploratory, descriptive and contextual research design was used in this study (Burns \& Grove 2003:61). The study aimed at exploring how fourth-year BCur students experienced the case study as a learning opportunity in order to make research-based recommendations to improve the use of the strategy. The study population consisted of 50 fourth-year BCur students. All students were invited, and only 24 students voluntarily agreed to participate in the study. The research question was, 'What are your experiences with regard to the use of a case study as a learning opportunity in clinical nursing education?'

\section{Data collection}

The use of the case study as a teaching strategy is implemented from the second year and increases as the level of training increases. The choice of fourth-year BCur students as participants was appropriate because they already had two academic years of exposure to the case study as a teaching strategy. The participants were asked to describe their experiences regarding the use of case studies as a learning opportunity. The participants were given sheets of papers to complete descriptive naïve sketches responding to the research question. The purpose of the study was explained to the participants who were also informed that they could withdraw from the study whenever they wanted to (Babbie \& Mouton 2002:521).

To ensure anonymity and confidentiality, the participants were instructed not to write their names on the response sheet and informed that the information obtained would be restricted to the researcher and the co-coder. The researcher collected field notes from the dynamics demonstrated by non-verbal and facial gestures from participants as they were writing. There was no time limit; however, all participants had finished writing after 35 minutes. The participants were assured that the descriptive naïve sketches would be kept safely under lock and key for two years following the publication of the study.

\section{Data analysis}

The researcher and the independent co-coder, who was purposively selected, analysed the data according to the method described by Tesch (cited in Creswell 1994:155). The process involved repeated, careful reading of the descriptive naïve sketches to make sense of the whole. Emerging common themes and concepts were identified and a list was compiled. Similar themes and concepts were clustered and arranged into three main categories. The researcher and the co-coder held a consensus meeting after two weeks to deliberate and agree on the identified themes and their related categories. A follow-up interview was held with 10 of the participants in the study to verify the themes and categories.

\section{Trustworthiness}

The trustworthiness of the study was maintained according to the principles of Lincoln and Guba (1985:290-327) as follows: 


\section{Credibility}

Credibility asks whether the researcher has established confidence in the truth of the findings for the participants and the context in which the study was undertaken. The credibility of the data was ensured by exploring the experiences of the participants who had been exposed to the use of a case study in different discipline contexts over a period of three and half years of their study at the university. The researcher had prolonged engagement with the data collected as she had to read the data repeatedly to be able to internalise the data and gain a meaningful understanding of the information (Lincoln \& Guba 1985:290). To ensure triangulation, varied and relevant primary and secondary sources were used to justify the study and to control the findings. Reflexivity was ensured through consensus discussion meetings of the researcher and the co-coder to arrive at similar themes and their related categories. Credibility was also ensured by follow-up interviews with 10 of the participants to verify the findings.

\section{Transferability}

Transferability refers to the degree to which the findings of a particular study can be applied to other contexts. It is the ability to generalise from the findings of the study to a larger population. By providing a dense description of the research design and method of the study, a potential transferability of the findings to other contexts may be made. The researcher is of the opinion that the recommendations made will positively influence the use of the case study throughout the clinical nursing education programme.

\section{Dependability and conformability}

Dependability as a principle to ensure trustworthiness considers the consistency of the data, that is, whether the findings would be consistent if the study was replicated with the same participants or in a similar context. The features of the study design and method are logically coherent with the research questions, aim, research design and method used in this study.

\section{RESULTS AND DISCUSSION}

22 out of 24 participants experienced the case study to be very beneficial and effective as a teaching and learning method. Three main categories that emerged from the data analysis include case study usage increases critical thinking; case study usage increases theory-practice integration and that case study usage increases growth in presentation skills are presented.

\section{Case study usage increases critical thinking}

Most of the participants were of the opinion that good case study presentation requires a good theoretical background and sound logical reasoning. A student should think critically during the assessment phase in which health problems are to be identified. More critical thinking is needed when, from the information gathered, the student has to make a diagnosis in order to plan for the identified problems. Critical thinking is described as the process of purposeful, self-regulatory judgment that includes the cognitive skills of interpretation, analysis, evaluation, inference, explanation, self-regulation and the related disposition (Oermann 1998:322).

Rational critical decisions are made that may not be exactly the same as book knowledge. Case studies promote perception learning in that the learners use all their senses to engage in real-life and authentic scenarios. Students are compelled to think beyond book knowledge because they can see, listen, hear and touch the patient; that is, case studies are based on real-life clinical situations. This notion is supported by Winningham and Preusser (2001:1) who asserted that as the students work through cases, they begin to understand how to take what they are learning from the books in the classroom and apply it to the patient care setting, thus gaining insight into how experienced nurses think.
Case studies do not leave room for rote learning. The key aspect is the application of knowledge, skills and attitudes to a specific situation. Students learn to 'think on their feet' and to be able to apply what they know quickly in a practical setting (Winningham \& Preusser 2001:1). Learners are drawn through realistic situations to information they believe is relevant and interesting. To add to this, critical thinking is an interactive process whereby the student encounters challenges through exposure to real problems. Students need to find the relevant information to solve those problems to react appropriately in a clinical situation. Establishing the usefulness or significance of the problems from insignificant problems requires critical thinking ability as does the making of an accurate analysis, synthesis and interpretation of information (Facione 1990:6).

During case study presentation, students make inferences; that is, they query claims, assess arguments by recognising faulty reasoning and reach conclusions that are appropriate to the care of the patients. Student nurses give clear explanations and defend their reasoning as to how they arrived at specific decisions when they present case studies. They give explanations for their thoughts, actions and feelings. They generate hypotheses on which patterns and relationships are constructed in order to arrive at specific nursing diagnoses. They draw conclusions based on evidence gathered during the assessment phase of the nursing process and also make interdisciplinary connections to enrich their understanding, which will help in the planning phase (Bandman \& Bandman 1998:6). If the plan does not meet the expected outcomes, students as critical thinkers have the capacity to explore alternatives after having revised their original plan based on more information gathered. They also have to evaluate the information gathered to ascertain its relevance to the patient (Facione 1990:6). As they present case studies, they constantly monitor their thinking, using the criteria for critical thinking such as clarity, precision, accuracy, logic, significance and self-correction, to ensure that it is appropriate in the context of caring for the patient (Paul 1993:54).

By engaging in critical thinking, students acquire new levels of understanding and expand their thought processes (Winningham \& Preusser 2001:2). Critical thinking is an analytical process that can help students to be flexible and to think through a problem in consultation with others in an open-minded, flexible, organised and efficient manner. These attributes are regarded as integral dispositions necessary to support the critical cognitive skills (Facione 1990:6, 13).

Case studies and case presentations make students inquisitive, curious and enthusiastic in wanting to acquire knowledge and skills. They develop a different approach to complex problems. Students gain self-confidence and trust their own reasoning when making rational clinical decisions based on scientific evidence (Facione 1990:13). Case studies encourage purposeful reasoned interaction among students and clinical situations or surrounding circumstances, hence the increasing call for instructional methods to develop critical thinking in nursing education in general and in clinical nursing education in particular where 'things happen' (Chabeli 2007:72).

\section{Case study usage increases theory-practice integration}

The students indicated that the use of the case study approach to facilitate learning helped them to integrate their biological, behavioural and nursing theoretical knowledge as they interacted directly with patients. Mention was also made of the dynamic nature of health care needs/problems in that the same health care need/problem does not always present itself in the same way for different patients.

Case studies differ in that some case studies describe histories of actual clients while other case studies, particularly those used for developing or assessing particular learning skills, such 
as sound judgment or problem solving, are examples based on situations that are known to occur. Irrespective of whether the case study is an individual or a small group encounter, it encourages student involvement and also provides substantive data and processes essential to an analysis of a specific situation whilst allowing the student to recognise the complexity and the ambiguity of the real practical environment. Therefore the case study has the power to improve the acquisition of knowledge, skills and attitudes in an integrated manner.

Students who are exposed to the use of case studies acquire knowledge not merely as words but they are also enabled to appropriately interpret and apply it in practice. Mellish et al. maintained that students also:

acquire skill in problem solving; organize ideas logically; practice higher levels of cognitive learning as they make inferences, apply theory, analyse and synthesize knowledge relevant to a specific situation and to evaluate the product.

(Mellish et al. 1998:181)

Attitudes and values are fixed in early life. However, as students engage in case study discussions amongst themselves in a relaxed, tension-free and non-evaluative atmosphere, a situation may arise that may lead them to re-examine their own personal attitudes and that, together with the experiences acquired in the clinical practice, may foster appropriate personal and professional attitude change or modification.

Case studies foster students' desire to engage in continued consultation with other health care practitioners such as doctors and allied health care personnel in order to acquire disciplinerelated knowledge about a specific condition. There is also a need for interaction and the development of an enquiring mind to optimise their practical nursing skills. Case studies compel students to read about research done on the same health condition in articles or books or obtain information from the Internet, and this exercise encourages the utilisation of findings, resulting in evidence-based practice. This is supported by a citation from participants as follows:

'Looking for the information ourselves using research findings to particular situations gives us the knowledge and insight of doing research to solve problems differently and improve nursing care by evaluation of some of the practices at the practice setting. It should be emphasised because it teaches us to be independent and confident in exploring information ourselves.

A positive aspect of case studies is that through case presentation, students are able to gain confidence and become aware of their limitations in terms of knowledge regarding the real-life situation, which may be different from book knowledge. The knowledge gained from real-life situations increases their practical, foundational and reflexive competence. According to the SAQA Act practical competence refers to the demonstration of the ability in an authentic context to consider a range of possibilities for action, make considered decisions about which possibilities to follow and perform the chosen action. It is grounded in foundational competence whereby the learner demonstrates the understanding, knowledge and thinking that underpin the action taken and integrates it through reflexive competence. In this, the learner demonstrates the ability to integrate or connect performance and decision making with understanding and with an ability to adapt to change and unforeseen circumstances and to explain the reasons behind these adaptations.

According to Quinn (1998:52), humanistic theory believes that adult learners are naturally self-directing and autonomous with regard to learning if given the opportunity to be so. According to Knowles (cited in Mellish et al. 1998:36), as adult learners mature, they show a tendency for self-directedness, self-monitoring and self-assessment, taking responsibility for their own learning through interaction and dialogical teaching methods such as the case study, debates and seminars. Adult learners' experiences act as a rich resource for learning to be used in the facilitation of learning. Adult learners experience the need to immediately apply the knowledge they have acquired to practice.

Theory and practice are concepts that are inseparable in the nursing profession. The gap between theory and practice leads to ineffective patient care because nurses have to justify and provide supporting evidence for their thoughts and actions. The use of the case study not only facilitates the development of integrative processes from within the individual student but also attempts to integrate theoretical components with learning experiences and activities (Ehrenberg \& Häggblom 2007:67; Quinn 1998:238, $386-387)$. The correlation of theory and practice and the creation of meaningful learning experiences for students should occur in clinical practice where there is real-life experience.

\section{Case study usage increases growth in presentation skills of students}

The Compact Oxford English Dictionary (Soanes \& Hawker 2005:804) defines a presentation as 'the way in which something is presented' and a skill as 'the ability to do something well'. According to the World Book Dictionary (Barnhart 1995:1647), 'Presentation refers to an act of giving, delivering, an offering to be seen or showing; Presentee as a person to whom something is presented; Presenter as a person who presents.' Therefore, in the context of this study, presentation skill refers to the ability of the student as a presenter to put across the information gathered through a case studied to fellow students, ward nursing staff and nurse educators as presentees in a semi-structured or structured way, either in a clinical or classroom setting.

Presenting a case study is not one of the easiest things to do. For many it can be both nerve wracking and stressful. Being able to express oneself clearly and convincingly is not only a skill required during student life but also continues beyond the practice of nursing as a professional nurse into one's personal and social life. An assumption is made that the key to good presentation is good preparation and that if the case has been studied and analysed thoroughly, the content of the presentation should present no problems. The following citation comes from the participant narratives:

'Lecturer gave us enough time to prepare; I was able to look for information, interview the patient and chat with family members.'

This suggests that in preparation for case presentation, students carefully analyse and interpret the patient's documented information, assess the patient's condition and consult other health care practitioners and allied health care personnel. They also search for information related to the condition of the patient from books, research articles and the Internet. These efforts are necessary not only to enable students to compile organised coherent presentations but also to discuss, debate, justify and integrate ideas. To fail to prepare is to prepare to fail. Good preparation leads to good presentation (Hamm \& Dunbar 2008:16).

This view is also shared by Sandstrom (2006:229) who stated that students prepared and compiled a case report for presentation by implementing scientific processes such as the nursing process to encourage the critical thinking and problem-solving process by studying, analysing, applying knowledge and standards, discriminating, seeking information, reasoning logically and predicting and transforming knowledge.

Students recognised the need to practise in order to become competent presenters. Hamm and Dunbar (2008:9) also believe that 'a well-planned and practiced [sic] presentation can be a memorable and pleasurable event for both the presenter and the audience.' The same view is shared by Ericsson and Charness (cited in Van Gelder sa:3) who 'found that excellence results primarily from a special sort of practice which he calls "deliberate".' The characteristics of deliberate practice are well defined. Deliberate action is carried out with full concentration and is aimed at generating improvement; it entails not only 
engaging in the skill itself but also doing special exercises such as case presentation, designed to improve performance in the skill. Practising in front of fellow students is also necessary because they provide valuable feedback that enhances skill perfection and knowledge retention. The following are some of the participant comments that highlight the essence of a wellprepared and well-rehearsed case presentation:

'Case studies are good because the students will show skills of looking for information about the patients and skills of presenting that information to other students and the evaluator. A case study involves good communication skills because the students will need the skills in order to communicate with the patients. Good presentations are based on proper and thorough preparations. Case presentation provides us with the ability to face your colleagues, building confidence, flexibility, courage and assertiveness.

The researcher as an educator is of the opinion that students as presenters should internalise their presentations well. An observation made during case presentation sessions was that students ensured that they were well prepared and presentable, thus portraying a professional image. This observation was also supported by Burman and Sherard (2007:238-239) in their study entitled 'Use of presentation examinations to teach evidence-based practice to student nurses' in which they found that, among others, students demonstrated that they took oral case presentation very seriously and did a great deal of preparation that they might not otherwise have done, even dressing professionally. However, lecturers are warned against assessment errors such as the 'halo effect', as they may be overwhelmed by professional and stylish dressing to impress the evaluator, resulting in students being rated highly and lecturers forgetting about what should really be observed during the presentation (Quinn 2000:234).

Inferences made from some of the participant narratives as cited below were that case presentation further enhances their cognitive, psychomotor and affective skills:

'By doing oral presentation of your case study you will deepen your insight in your specific case; continue to learn by listening to the fellow students' presentations. It does not end there because one acquires interpersonal skills.Knowing your staff makes one to develop in one's own confidence, courage, assertiveness and taking ownership in one's actions.'

The ability of the student to present is not developed through a once-off case presentation; instead, the skill of presenting is continuously refined over time through constant repeated exposure to the use of the case study as a learning opportunity throughout the student's four years of study at the university (Hamm \& Dunbar 2008:5). This is supported by the following participant comments:

'I think it should be done with all the subjects especially Midwifery; Well at first one becomes frightened but as one gets used to it, it enhances competency. You cannot get more experience by doing one case study. I think it is better if you can do case study presentation in all the wards you are allocated to. I feel that case study presentation should be encouraged in all levels of study.

The presentee actively listens to gain knowledge and understanding of the case being presented, to ask appropriate questions for clarity and to reflect on his or her own case study and on the past case presented. The case study presentation also incorporates the idea that students can learn from one another:

'by engaging with each other and with each other's ideas, by asserting something and then having it questioned, challenged and thrown back at them so that they can reflect on what they hear and then refine what they say.'

Students can direct their own learning by formulating questions and taking responsibility for the study.

During the case presentation sessions, questions may be directed by the presentees to the presenter or by the presentees/presenter to the nurse educator for various reasons. Billings and Kowalski (2007:200) described questions in a learning environment, such as case presentation, as stimulating the brain by serving as a power button; creating a climate of information exchange whereby the student as a presentee/presenter attempts to respond in some informative way; discovering knowledge or issues that the nurse educator is interested in; discovering what the student knows or what the plan is for a patient in a given case; encouraging listening because the process of active listening supports both constructive communication patterns and the demonstration of interest and concern; and providing an opportunity for acknowledgement, which is a powerful tool in the establishment of relationships. Nurse educators should respond in a way that is person-to-person oriented, specific to the case information provided, genuine and timely and that leads to a process of discovery whereby during the case presentation, a student can be led to an 'aha' moment, that is, a moment of realisation or discovery. It is more powerful and enriching to discover knowledge on one's own than being spoonfed with answers.

The nurse educator becomes an integral learning resource because during case presentations, he or she is expected to be knowledgeable about the subject, informed about group dynamics and an astute observer of human behaviour. The nurse educator is expected to facilitate, guide and direct the case presentation or to place emphasis on key points and clarify uncertainties when the need to do so arises (Mellish 1998:181).

The nurse educator also provides time cues to the timekeeper throughout the session in order to enable students to observe the pacing of the content. This exercise aids the students in their revisions for the subsequent case presentation (Little 2006:134).

Whilst facilitating case presentations, nurse educators appreciate the importance of personal interaction with students. Getting to know one's students and showing interest in them certainly makes them more interested in the core business of learning and allows them to focus and feel a really important part of the class or ward. Nurse educators will try to address students using their names when asking questions. The use of names in case presentation allows a very simple positive feedback mechanism by referring back to correct answers that students have provided earlier, using phrases like 'Regarding what so and so said earlier, his/her point was really important for what we are talking about now because...' This not only provides an opportunity for students to reinforce what they have learnt but also strengthens other skills acquired through case presentations. During these case presentations, nurse educators will critically observe communication skills, logical flow of ideas and thoughts and structuring of the content. The feedback that the nurse educator gives should be aimed at further refining of the student's knowledge, skills, attitudes, values and presentation skills. Those students who did not prepare and present as expected should be subjected to a structured remediation programme (Haydensheets \& Tillson 2006:5).

\section{CONCLUSION}

Based on the findings of the study, it becomes clear that there is a need to increase the use of case studies and case presentations to facilitate effective teaching and learning at all levels of nurse training. The nurse educator as a facilitator of learning should create an environment conducive to the effective use of a case study as a teaching method to facilitate the critical thinking of learners.

\section{REFERENCES}

Babbie, E. \& Mouton, J., 2002, The practice of social research, Oxford University Press, Cape Town.

Bandmann, L. \& Bandmann, B., 1998, Critical thinking in nursing, Appleton \& Lange, New York.

Barnhart, R.K. (ed.), 1995, The world book dictionary, vol. 2, L-Z, World Book, London. 
Billings, D.M. \& Kowalski, K., 2007, 'The value of asking questions', Journal of Continuing Education in Nursing 38(5), 200.

Burman, M.E. \& Sherard, P., 2007, 'Use of oral examinations to teach concepts of evidence-based practice to nurse practitioner students', Journal of Nursing Education 46(5), 238-342.

Burns, N. \& Grove, S.K., 2003, The practice of nursing research: Conduct, critique and utilization, WB Saunders, Toronto.

Chabeli, M.M., 2007, 'Facilitating critical thinking within the nursing process framework: A literature review', Health $S A$ / Gesondheid 12(4), 69-89.

Conyers, V. \& Ritchie, D., 2001, 'Case study tests: Assessment directing learning', Journal of Nursing Education 40(1), 40-42.

Creswell, J.W., 1994, Research design: Qualitative and quantitative approaches, Sage Publications, New Delhi.

Draude, B.J., 1996, 'Use of master classroom technology to implement a case study approach to learning', MidSouth instructional technology conference proceedings, Tennessee, March 31-April 2, n.p.

Ehrenberg, A.C. \& Häggblom, M., 2007, 'Problem-based learning in clinical nursing education: Integrating theory and practice', Nurse Education in Practice 7, 67-74.

Facione, P.A., 1990, Critical thinking: A statement of expert consensus for purposes of educational assessment and instruction, Executive summary: The Delphi Report, Academic Press, Millbrae.

Hamm, P.H. \& Dunbar, N.R., 2008, Teaching persuasive communication: Class presentation skills, a handbook for faculty, teaching assistants and teaching fellows, Brown University, Rhode Island.

Hannah, V., 2006, 'The big picture: Learning to think like a nurse', Journal of Nursing Education, 45(6), 239-340.

Haydensheets, B.B. \& Tillson, L., 2006, 'Strategies to improve students' presentation skills', Journal of Applied Topics in Business and Economics, viewed July 2008, from http://www. westqa.edu/ bquest/.
Lincoln, Y.S. \& Guba, E.G., 1985, Naturalistic inquiry, Sage Publications, London.

Little, M., 2006, 'Preparing nursing students to be health educators: Personal knowing through performance and feedback workshops', Journal of Nursing Education 45(3), 131-135.

Mellish J.M., Brink, H.I.L. \& Paton, F., 1998, Teaching and learning the practice of nursing, Heinemann, Johannesburg.

Oermann, M., 1998, 'How to assess critical thinking', Journal of Advanced Nursing 17, 1401-1407.

Paul, R., 1993, Critical thinking: What every person needs to survive in a rapidly changing world, Foundation for Critical Thinking, Santa Rosa.

Quinn, F.M., 1998, The principles and practice of nursing education, Croom Helm, London.

Sandstrom, S., 2006, 'Use of case studies to teach diabetes and other chronic illnesses to nursing students', Journal of Nursing Education 45(6), 229-232.

Schryer, C.F., Lingard, L., Spafford, M. \& Garwood, K., 2003, Structure and agency in medical case presentations, writing selves/writing societies, viewed July 2008, from http://wac. colostate.edu/books/selves_societies/.

Soanes, C. \& Hawker, S. (eds.), 2005, Compact Oxford English dictionary, Oxford University Press, New York.

South Africa, 1995, Qualification Authority Act 58 of 1995, Government Printers, Pretoria.

South African Nursing Council, 1985, Regulations relating to the approval of and the minimum requirements for the education and training of a nurse (general, psychiatric and community) and midwife, leading to registration. R.425 of 22 February 1985, Government Printers, Pretoria.

Van Gelder, T., 2005, 'Teaching critical thinking: Some lessons from cognitive science', College Teaching 53(1), n.p.

Winningham, M.L. \& Preusser, B.A., 2001, Critical thinking in medical-surgical setting: A case study approach, Mosby, St Louis. 